\title{
NITRATE REMOVAL FROM WATER USING SURFACE-MODIFIED ULTRAFILTRATION MEMBRANES
}

\author{
Mirna Habuda-Stanić \\ Josip Juraj Strossmayer University of Osijek, Faculty of Food Technology Osijek, Assistant Professor \\ Marija Nujić \\ Josip Juraj Strossmayer University of Osijek, Faculty of Food Technology Osijek, Assistant \\ Vera Santo \\ Public Health Institute of the Osijek-Baranja County, Osijek, B.Sc.
}

\begin{abstract}
Elevated nitrate concentrations in natural water sources are a worldwide concern due to the extensive levels of soil $\mathrm{N}$-fertilization. This study investigates three commercially available polyethersulfone (PES) ultrafiltration (UF) membranes with different molecular weight cut-offs $(5,10$, and $30 \mathrm{kDa})$, which we modified with a cationic surfactant, cetylpyridinium chloride to improve their nitrate removal. The nitrate removal efficiency of these membranes was examinated as functions of initial nitrate concentration, $\mathrm{pH}$, and permeate flux. The best nitrate removal efficiency was obtained with a $5 \mathrm{kDa}$ surface-modified UF membrane.
\end{abstract}

Key words: nitrate removal, UF membrane, permeate flux, cetylpyridinium chloride, membrane surfacemodificaton

\section{UKLANJANJE NITRATA IZ VODE POVRŠINSKI MODIFICIRANIM ULTRAFILTRACIJSKIM MEMBRANAMA}

Sažetak: Pojava povećanih koncentracija nitrata u prirodnim vodama diljem svijeta najčešće je posljedica prekomjerne uporabe mineralnih gnojiva u poljoprivredi. $U$ ovom radu ispitana je mogućnost primjene tri komercijalno dostupne površinski modificirane polietersulfonske (PES) ultrafiltracijske (UF) membrane s različitim graničnim molekulskim masama $(5,10$ and $30 \mathrm{kDa})$. Površinska modifikacija UF membrana načinjena je primjenom surfaktanta cetilpiridin klorida. Učinkovitost uklanjanja nitrata ispitana je ovisno o početnoj koncentraciji nitrata, pH vrijednosti otopine i fluksu permeata. Najbolji učinak postignut je primjenom površinski modificirane membrane s graničnom molekularnom masom od $5 \mathrm{kDa}$.

Ključne riječi: uklanjanje nitrata, UF membrane, fluks permeata, cetilpiridin klorid, površinska modifikacija membrane 


\section{Introduction}

Nitrate, due to its high water solubility, is possibly the most widespread groundwater contaminant in the world, seriously threatening supplies of drinking water and promoting eutrophication [1]. Oxides of nitrogen, such as nitrate and nitrite, are common pollutants in water resources and various types of agricultural, domestic, and industrial wastewater [2]. High nitrate levels in drinking water have been associated with increased $\mathrm{N}$ nitrosoproline levels in urine, and nitrate administered via drinking water has been shown to be directly related to the concentrations of $\mathrm{N}$-nitroso compounds (NOC) in feces. Water containing significant concentrations of nitrate can cause methemoglobinemia in infants, also known as "blue baby syndrome", while some studies have emphasized the relationship between nitrate levels in drinking water and cancer incidence [3, 4]. For these reasons, the US Environmental Protection Agency (EPA) and the World Health Organization (WHO) have defined

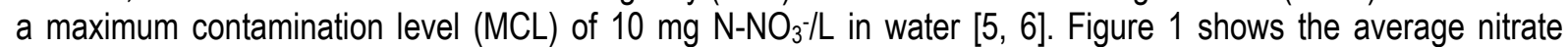
concentrations in groundwater from 27 water-wells in eastern Croatia, a site of intensive agriculture over recent decades. These nitrate concentrations were measured throughout 2011 under different hydrological conditions.

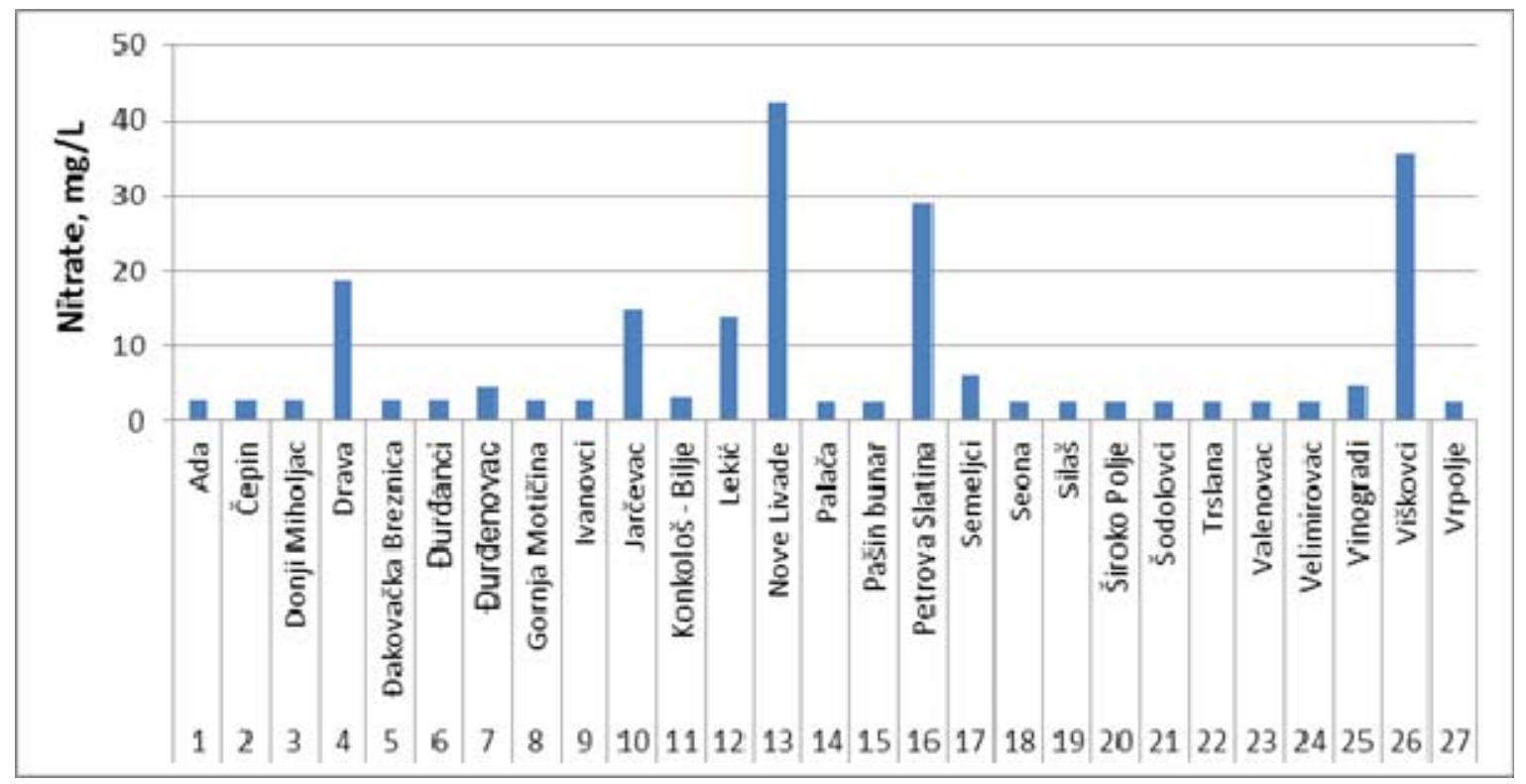

Figure 1. Nitrate concentrations in groundwater from 27 water-wells in eastern Croatia

Various technologies have been used to remove nitrate from drinking water, including reverse osmosis, ultrafiltration, ion exchange, ion-exchange-membrane bioreactors, catalytic reduction, electrodialysis, activated carbon, land disposal, chemical denitrification, and microbiological treatment $[1,2,7]$. Although these techniques effectively remove nitrate from contaminated water, they are very expensive to implement in pilot-scale programs, limiting their potential application. Of these technologies, the most versatile and widely used is biological denitrification [8] which uses an anoxic environment to completely remove nitrate; the chemically bound oxygen in nitrate acts as a terminal electron acceptor, liberating nitrogen $\left(\mathrm{N}_{2}\right)$ gas without generating brine as a by-product $[9,10,11]$. However, membrane filtration has been increasingly used to remove various contaminants from water [12-16]. Tight membrane filtration methods such as reverse osmosis (RO) filtration and nanofiltration (NF) can effectively remove nitrate from contaminated water, but such dense membranes are relatively costly and require electricity.

Several studies have shown that micellar-enhanced ultrafiltration can effectively remove organic and inorganic pollutants from aqueous phases [12, 14, 17-21]. In the present article, we investigate nitrate removal by using three commercially available cross-flow polyethersulfone UF-membranes with different molecular-weight cut-offs (MWCOs). We found that the selectivity of the UF membranes could be improved by filtering a cationic surfactant cetylpyridinium chloride (CPC) solution through them. 


\section{Materials and Methods}

Cetylpyridinium chloride (CPC; $99 \%$ pure) was obtained from Sigma-Aldrich (USA), and $\mathrm{KNO}_{3}$ was obtained from Alkaloid (Republic of Macedonia). A model nitrate solution was prepared with deionized (DI) water and $\mathrm{KNO}_{3}$ as follows: $1.6305 \mathrm{~g} \mathrm{KNO}_{3}$ was dissolved in $1000 \mathrm{~mL}$ deionized water to obtain $1 \mathrm{mg} / \mathrm{mL} \mathrm{NO}_{3}$. This stock solution was diluted with $\mathrm{DI}$ water to concentrations of 60,90 , and $120 \mathrm{mg} / \mathrm{L}$. The $\mathrm{pH}$ was adjusted using $0.1 \mathrm{M} \mathrm{NaOH}$ and $\mathrm{KCl}$. The CPC solutions were prepared to concentrations of $1.0 \mathrm{mM}$, above the critical micelle concentration (CMC) when the surfactant forms micelles comprising up to 100 surfactant molecules. $1000 \mathrm{~mL}$ of the CPC solution was filtered through each membrane prior to filtering the nitrate solution. Three cross-flow polyethersulfone UF membranes (Biomax 5, Biomax 10, and Biomax 30; Millipore, USA) were used. These membranes had effective areas of $0.050 \mathrm{~m}^{2}$ and molecular weight cut-offs (MWCOs) of 5,10 , and $30 \mathrm{kDa}$, respectively. Each membrane was fitted to a Pellicon XL laboratory-scale UF cell (Fig. 2), which had a peristaltic pump with adjustable speed (60-600 rpm/min) and adjustable capacity (optimal range of $30-50 \mathrm{~mL} / \mathrm{min}$ ). Before ultrafiltration, the permeate flux $(J)$ of the feed was adjusted to 35,65 , or $85 \mathrm{~L} / \mathrm{m}^{2} \mathrm{~h}$. The permeate flux was adjusted by measuring the time needed to collect $25 \mathrm{~mL}$ of permeate by filtering DI water. The permeate flux was calculated by the following equation:

$$
J=Q_{p} / S
$$

where $Q_{p}$ is the permeate flow rate $(L / h)$ and $S$ is the membrane surface area $\left(\mathrm{m}^{2}\right)$.

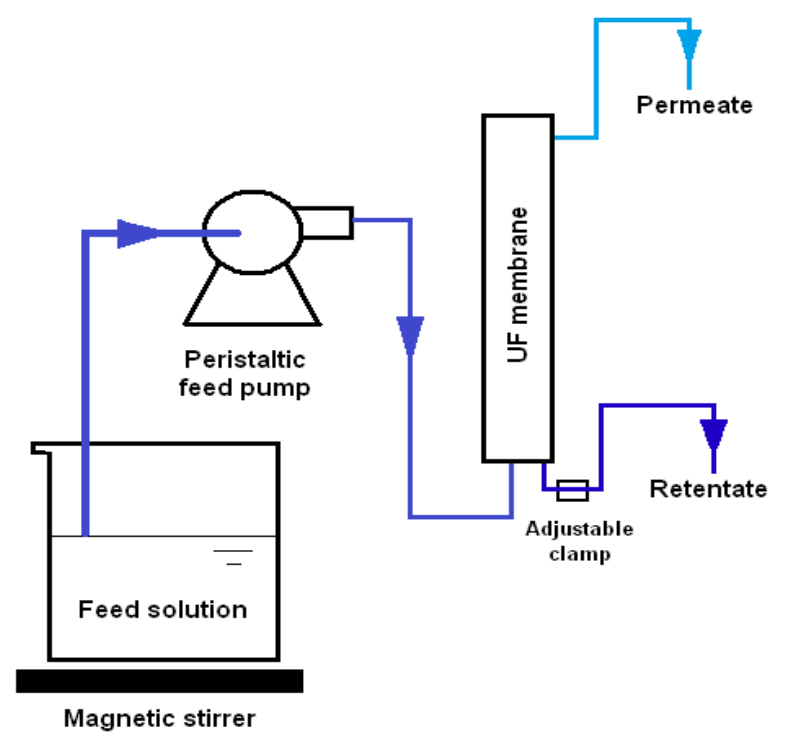

Figure 2. Schematic of the Pellicon XL ultrafiltration unit

In accordance with manufacturer instructions, the permeate flux through the membrane was adjusted with clamps attached on the retentate outlet conduit. After the permeate flux was established, $150 \mathrm{~mL}$ of nitrate feed solution was released, and then $300 \mathrm{~mL}$ of permeate was captured for analyses. Nitrate rejection was measured as a function of the initial nitrate concentration $(60,90$, and $120 \mathrm{mg} / \mathrm{L}), \mathrm{pH}(6-8)$, and permeate flux $(\mathrm{J}=35,65$, and $85 \mathrm{~L} / \mathrm{m}^{2} \mathrm{~h}$ ). The nitrate concentrations were determined by the nitrate electrode method using an ion-selective electrode (Seven Easy, Mettler Toledo, USA) [22]. Nitrate removal (R) was calculated with the following equation:

$$
R=\left(\frac{C_{i}-C_{p}}{C_{i}}\right) \times 100
$$

where $C_{i}$ is the feed concentration of nitrate and $C_{p}$ the permeate concentration of nitrate. 


\section{Results and Discussion}

\subsection{Influence of pH on Nitrate Removal}

Figures 3-5 show how nitrate removal varied with various membranes and at permeate fluxes of 35,65 , and 85 $\mathrm{J} / \mathrm{m}^{2} \mathrm{~h}$, respectively. As the MWCO increased, the nitrate removal efficiency decreased. The nitrate was efficiently removed with a surface-modified Biomax 5 at a permeate flux of $35 \mathrm{~J} / \mathrm{m}^{2} \mathrm{~h}$ and an initial nitrate concentration of 60 $\mathrm{mg} / \mathrm{L}$. The greatest nitrate rejection of $34 \%$ occurred at pH 8 [Fig. 3(a)]. In general, when pH increased, the removal efficiency increased, except for an initial nitrate concentration of $120 \mathrm{mg} / \mathrm{L}$ [Fig. 3(c)]. In this case, the highest removal efficiency occurred at pH 7.5. The surface-modified Biomax 10 and Biomax 30 membranes exhibited lower nitrate removal efficiency than the surface-modified Biomax 5 membrane.
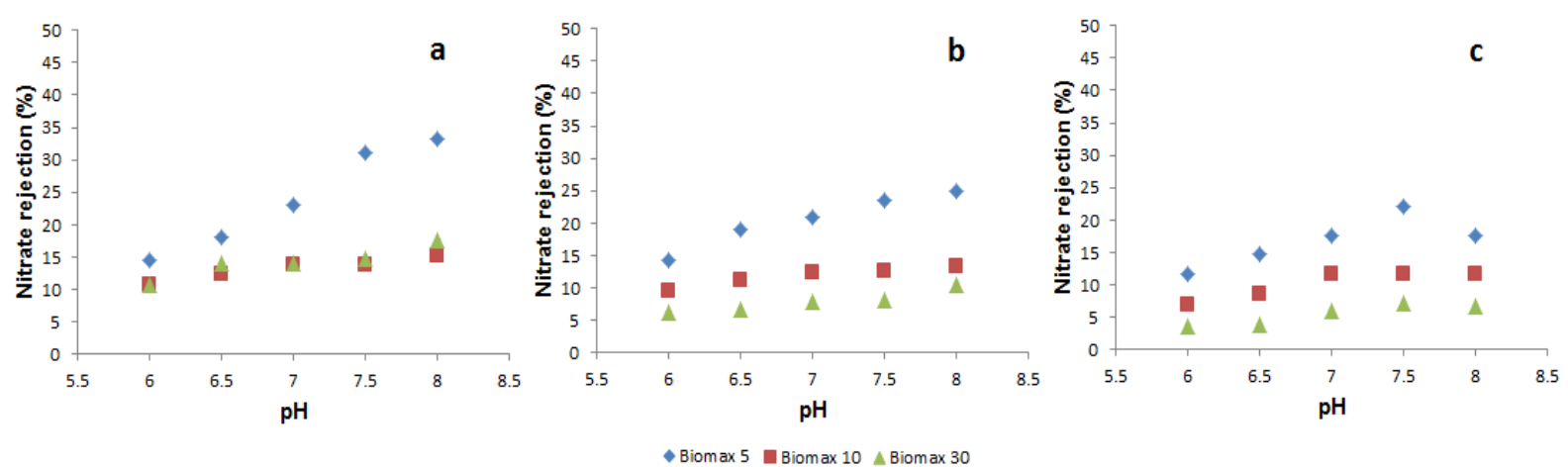

Figure 3. Nitrate rejection by UF membranes at permeate flux of $35 \mathrm{~J} / \mathrm{m}^{2} \mathrm{~h}$ and various nitrate concentrations: a) $60 \mathrm{mg} / \mathrm{L}$, b) $90 \mathrm{mg} / \mathrm{L}$, c) $120 \mathrm{mg} / \mathrm{L}$

At a permeate flux of $65 \mathrm{~J} / \mathrm{m}^{2} \mathrm{~h}$, decreasing the $\mathrm{pH}$ also decreased nitrate removal; the highest nitrate rejection was achieved at pH 7.5. At $85 \mathrm{~J} / \mathrm{m}^{2} \mathrm{~h}$, the highest nitrate removal $(19 \%)$ occurred at $\mathrm{pH} 7.5$ with a Biomax 5 membrane at an initial nitrate concentration of $90 \mathrm{mg} / \mathrm{L}$.

\subsection{Influence of Initial Nitrate Concentration on Nitrate Removal}

As shown in Fig. 3(a), at a permeate flux of $35 \mathrm{~L} / \mathrm{m}^{2} \mathrm{~h}$, nitrate removal increased with decreasing concentration; the highest nitrate removal (33\%) occurred at an initial nitrate concentration of $60 \mathrm{mg} / \mathrm{L}$. At permeate fluxes of 65 and $85 \mathrm{~L} / \mathrm{m}^{2} \mathrm{~h}$, nitrate rejection was almost independent of concentration in the studied range. At $65 \mathrm{~L} / \mathrm{m}^{2} \mathrm{~h}$, the highest nitrate removal (over 37\%) occurred at the highest nitrate concentration (120 mg/L), as shown in Fig. 3(c); at $85 \mathrm{~L} / \mathrm{m}^{2} \mathrm{~h}$ and the same initial nitrate concentration, only $13 \%$ of the nitrate was removed.
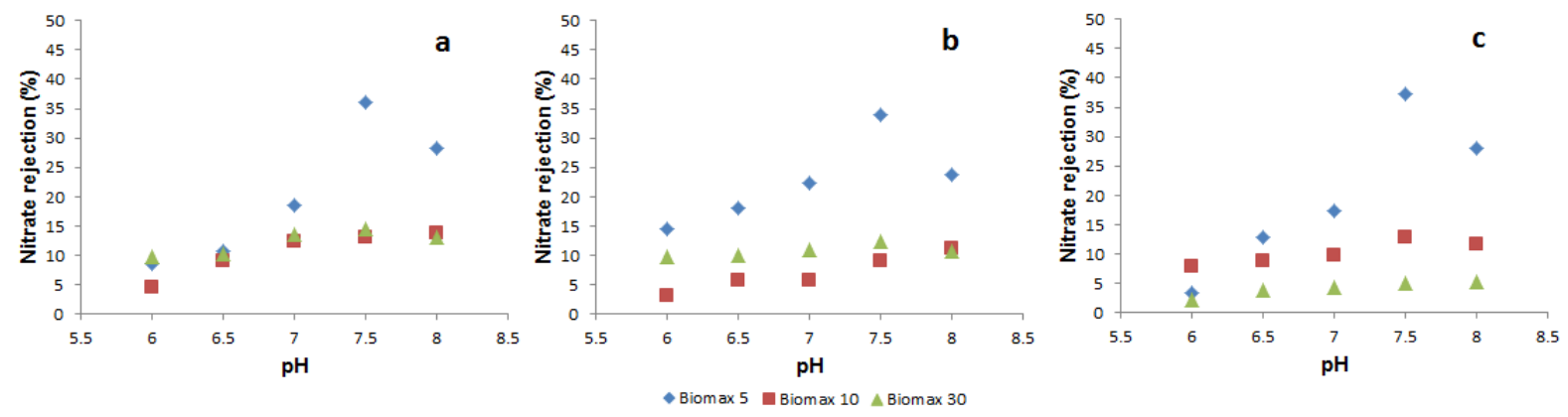

Figure 4. Nitrate rejection by UF membranes at permeate flux of $65 \mathrm{~J} / \mathrm{m}^{2} \mathrm{~h}$ and various nitrate concentrations: a) $60 \mathrm{mg} / \mathrm{L}$, b) $90 \mathrm{mg} / \mathrm{L}$, c) $120 \mathrm{mg} / \mathrm{L}$ 
The highest removal efficiency was achieved with a Biomax 5 membrane at an initial concentration of 120 $\mathrm{mg} / \mathrm{L}$ [Fig. 4(c)]. This membrane could be used as a household filter for drinking water to remove nitrate at concentrations slightly over the maximum concentration level (MCL).

\subsection{Influence of Permeate Flux on Nitrate Removal}

Our results show that the optimum permeate flux for nitrate removal was $65 \mathrm{~L} / \mathrm{m}^{2} \mathrm{~h}$. At $35 \mathrm{~L} / \mathrm{m}^{2} \mathrm{~h}$, the removal efficiency was somewhat lower, while at $85 \mathrm{~L} / \mathrm{m}^{2} \mathrm{~h}$ all the examined membranes exhibited low removal efficiency. The highest nitrate removal (37\%) occurred with the Biomax 5 membrane at a permeate flux of $65 \mathrm{~L} / \mathrm{m}^{2} \mathrm{~h}$ [Fig. $4(c)]$.
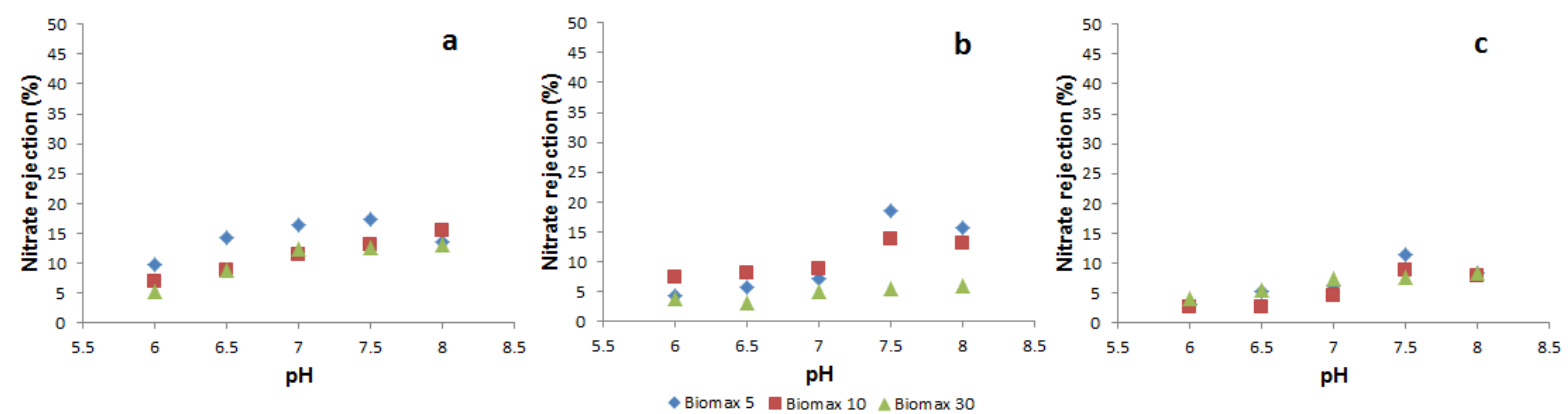

Figure 5. Nitrate rejection by UF membranes at permeate flux of $85 \mathrm{~J} / \mathrm{m}^{2} \mathrm{~h}$ and various nitrate concentrations: a) $60 \mathrm{mg} / \mathrm{L}$, b) $90 \mathrm{mg} / \mathrm{L}$, c) $120 \mathrm{mg} / \mathrm{L}$

\section{Conclusions}

In this article, we modified the surfaces of various ultrafiltration membranes with molecular weight cut-offs (MWCOs) of 5,10 , and $30 \mathrm{kDa}$ using cetylpyridinium chloride cationic surfactant. We then tested the membranes for nitrate removal from water at various initial nitrate concentrations $(60,90$, and $120 \mathrm{mg} / \mathrm{L})$, pH values (6-8), and permeate fluxes $\left(\mathrm{J}=35,65\right.$, and $\left.85 \mathrm{~L} / \mathrm{m}^{2} \mathrm{~h}\right)$. The membrane with the highest nitrate removal efficiency (up to $37 \%$ ) had an MWCO of $5 \mathrm{kDa}$; the membranes with MWCOs of 10 and $30 \mathrm{kDa}$ exhibited much lower removal efficiency under the same conditions. The $5 \mathrm{kDa}$ membrane achieved its highest nitrate removal efficiency at $\mathrm{pH}$ 7.5 , specific flow of $\mathrm{J}=65 \mathrm{~L} / \mathrm{m}^{2} \mathrm{~h}$, and initial nitrate concentration of $120 \mathrm{mg}^{\prime} \mathrm{L} \mathrm{NO} 3^{-}$. These results show that a surface-modified UF membrane with an MWCO of $5 \mathrm{kDa}$ can be applied as home-filtration system to remove nitrates present in drinking water at slightly higher concentrations than the maximum concentration level.

\section{References}

[1] Bhatnagar A.; Sillanpää M. 2011: A review of emerging adsorbents for nitrate removal from water, Chemical Engineering Journal, Volume 168, pp. 493-504

[2] Tofighy M. A.; Mohammadi T. 2012: Nitrate removal from water using functionalized carbon nanotube sheets, Journal of Hazardous Materials, Volume 90, pp. 1815-1822

[3] Yang C.-Y.; Wu D.-C.; Chang C.-C. 2007: Nitrate in drinking water and risk of death from colon cancer in Taiwan, Environment International, Volume 33, pp. 649-653

[4] Bryan N. S.; van Grinsven H. 2013: Chapter Three - The Role of Nitrate in Human Health, Advances in Agronomy, Volume 119, pp. 153-182

[5] US EPA; Water: Basic Information about Regulated Drinking Water Contaminants: Basic Information about Nitrate in Drinking Water. Available on: http://water.epa.gov/drink/contaminants/basicinformation/nitrate.cfm, Accessed 17 June 2014 
[6] World Health Organization (WHO); Nitrate and nitrite in drinking water, Background document for development of WHO Guidelines for Drinking water Quality, WHO/SDE/WSH/07.01/16 /Rev/1

[7] Santafé-Moros A.; Gozálvez-Zafrilla J. M.; Lora-García J. 2005: Performance of commercial nanofiltration membranes in the removal of nitrate ions, Desalination, Volume 185, pp. 281-287

[8] Kapoor, A.; Viraraghavan, T. 1997: Nitrate Removal From Drinking Water-Review, Journal of Environmental Engineering, 123(4), pp. 371-380

[9] Ovez B.; Ozgen S.; Yuksel M. 2006: Biological denitrification in drinking water using Glycyrrhiza glabra and Arunda donax as the carbon source, Process Biochemistry, Volume 41, Issue 7, pp. 1539-1544

[10] Ayyasamy P. M.; Shanthi K.; Lakshmanaperumalsamy P.; Lee S.-J.; Choi N.-C.; Kim D.-J. 2007: Two-stage removal of nitrate from groundwater using biological and chemical treatments, Journal of Bioscience and Bioengineering, Volume 104, Issue 2, pp. 129-134

[11] Zhao Y.; Zhang B.; Feng C.; Huang F.; Zhang P.; Zhang Z.; Yang Y.; Sugiura, N. 2012: Behavior of autotrophic denitrification and heterotrophic denitrification in an intensified biofilm-electrode reactor for nitrate-contaminated drinking water treatment, Bioresource Technology, Volume 107, pp. 159-165

[12] Baek K.; Yang J.-W. 2004: Cross-flow micellar-enhanced ultrafiltration for removal of nitrate and chromate: competitive binding, Journal of Hazardous Materials, Volume B108, pp. 119-123

[13] McAdam E. J.; Judd S. J. 2006: A review of membrane bioreactor potential for nitrate removal from drinking water, Desalination, Volume 196, pp. 135-148

[14] Geckeler K. E. 1996: Removal of hazardous substances from water using ultrafiltration in conjunction with soluble polymers, Environmental Science and Technology, Volume 30, Issue 3, pp. 725-734

[15] Kurama H.; Poetzschke J.; Haseneder R. 2002: The application of membrane filtration for the removal of ammonium ions from potable water, Water Research, Volume 36, pp. 2905-2909

[16] M'Bareck C. O.; Nguyen Q. T.; Alexandre S.; Zimmerlin I. 2005: Fabrication of ion-exchange ultrafiltration membranes for water treatment I. Semi-interpenetrating polymer networks of polysulfone and poly(acrylic acid), Journal of Membrane Science, Volume 278, pp. 10-18

[17] Zhu X.; Choo K.-H.; Park J.-M. 2006: Nitrate removal from contaminated water using polyelectrolyteenhanced ultrafiltration, Desalination, Volume 193, pp. 350-360

[18] Samper E.; Rodríguez, M.; De la Rubia, M. A.; Prats, D. 2009: Removal of metal ions at low concentration by micellar-enhanced ultrafiltration (MEUF) using sodium dodecyl sulfate (SDS) and linear alkylbenzene sulfonate (LAS), Separation and Purification Technology, Volume 65, pp. 337-342

[19] Huang, J.; Peng, L.; Zeng, G.; Li, X.; Zhao, Y.; Liu, L.; Li, F.; Chai, Q. 2014: Evaluation of micellar enhanced ultrafiltration for removing methylene blue and cadmium ion simultaneously with mixed surfactants, Separation and Purification Technology, Volume 125, pp. 83-89

[20] Tanhaei, B.; Chenar, M. P.; Saghatoleslami, N.; Hesampour, M.; Laakso, T.; Kallioinen, M.; Sillanpää, M.; Mänttäri, M. 2014: Simultaneous removal of aniline and nickel from water by micellar-enhanced ultrafiltration with different molecular weight cut-off membranes, Separation and Purification Technology, Volume 124, pp. 26-35

[21] Susanto, H.; Ulbricht, M. 2006: Performance of surface modified polyethersulfone membranes for ultrafiltration of aquatic humic substances, Desalination, Volume 199, pp. 384-386

[22] APHA; AWWA; WEF 1998: Part 4500 D, Nitrate Electrode Method, Standard Methods for the Examination of Water and Wastewater, $20^{\text {th }}$ Edition, Washington, D.C. 